\title{
NEOSPORA CANINUM IS ASSOCIATED WITH ABORTION IN ALGERIAN CATTLE
}

\author{
Farida Ghalmi ${ }^{\star}$, Bernard China†, Rachid Kaidił, and Bertrand Losson \\ Ecole Nationale Supérieure Vétérinaire d'Alger, Algiers, Algeria. e-mail: fghalmi@yahoo.fr
}

\begin{abstract}
Neospora caninum is a major cause of abortion in cattle worldwide. However, little information is available for Algeria. Accordingly, 799 cattle from 87 farms in the north and northeast of Algeria were enrolled in a seroepidemiological survey. An indirect fluorescence antibody test (IFAT) revealed a seroprevalence of $19.6 \%$. The animals were divided into 3 groups according to their breed: imported European cattle, local breeds, and crossed animals (European $\times$ local). Seroprevalences were 16.0\%, 34.3\%, and 18.6\% in groups 1,2, and 3, respectively. A case control study was performed to investigate the link between global seropositivity to $N$. caninum and abortion risk in those cattle farms. There was a significant $(P<0.01)$ association between the seroprevalence against $N$. caninum and the occurrence of abortion in those farms (odds ratio $[\mathrm{OR}]=12.03$ ). This was also observed at the individual level $(\mathrm{OR}=2.79)$. The analysis of results according to the breed revealed a significant association between seroprevalence and abortion in groups 1 and 3 , but not for group 2, despite the fact that the highest seroprevalence was observed in group 2. Cerebral tissues from 5 aborted fetuses were available for histology and polymerase chain reaction (PCR). One sample was found positive both by histology and by PCR, 2 samples were positive by PCR only, and 2 samples were negative in both tests.
\end{abstract}

Neospora caninum is an apicomplexan protozoon responsible for abortion and neonatal mortality in cattle worldwide (Dubey et al., 2007). This parasite has a heteroxenous life cycle, with the dog as definitive host and cattle as the main intermediate host (McAllister et al., 1999; Dubey et al., 2006). In dogs, N. caninum can cause neuromuscular disorders and death (Lindsay and Dubey, 2000), but, most of the time, the infection is asymptomatic (Dubey and Lindsay, 1993). Dogs produce fecal oocysts, which are infective for cattle. After ingestion and release of tachyzoites from oocysts, the parasites enter epithelial cells in the gut wall; some may eventually enter the placenta, leading to fetal infection. After the induction of a specific immune response, cysts are formed in the neural and muscular tissues. These cysts are packed with slow-replicating bradyzoites, which are able to survive for very long periods of time (Lindsay et al., 1992). In adult cattle, abortion is the only clinical sign. The vertical transmission involves the transmission of the parasite from an infected cow to the fetus, which is a consequence of oocyst ingestion (exogenous vertical transmission) or the activation of a chronic latent infection (endogenous vertical transmission). Depending on the stage of pregnancy, this can lead to abortion, the birth of a healthy, but chronically infected, calf, or, rarely, the birth of a clinically affected animal (Dubey et al., 2006). The presence of dogs on a cattle farm is considered as a risk factor for $N$. caninum abortion (Dubey et al., 2007; Ghalmi, Dramchini et al., 2009).

Serology is widely used to diagnose the infection, but also for the conduct of wide-scale epidemiological studies. Several serologic techniques are used, including indirect immunofluorescence antibody test (IFAT) and different immunoenzymatic assays (ELISA) (Dubey et al., 1988; Wouda et al., 1998; Ghalmi et al., 2009a). Immunoblots were also used as a confirmation method with the advantage of being able to determine the molecular weight of the reactive antigens (Dubey and Schares, 2006). Serology was used to evaluate the prevalence of $N$. caninum in bovines worldwide (Dubey et al., 2007). Depending on the study, prevalence varied considerably (Dubey et al., 2007; Ghalmi et al., 2007).

More recently, classic (Müller et al., 1996; Payne and Ellis, 1996; Yamage et al., 1996), nested (Baszler et al., 1999; Paula

Received 15 May 2011; revised 4 July 2011; accepted 5 July 2011.

* Université de Liège, Faculté de Médecine Vétérinaire, Liège, Belgium.

$\dagger$ Institut Scientifique de Santé Publique, Brussels, Belgium.

† University Saad Dahlab of Blida, Blida, Algeria.

DOI: 10.1645/GE-2861.1 et al., 2004), or real-time polymerase chain reaction (PCR) (Müller et al., 2002; Ghalmi et al., 2008) methods have been developed to detect $N$. caninum in dogs and cattle. Case control studies are efficient epidemiological tools used to investigate the relationship between a disease and a particular factor. Some case control studies were performed to investigate the role of $N$. caninum in cattle abortion (Davison et al., 1999; De Meerschman et al., 2000; Sager et al., 2001; Vaclavek et al., 2003). All studies indicated a clear association between seroprevalence and abortion in cattle. In aborted fetuses, the association of brain lesions (nonsuppurative encephalomyelitis and necrosis) and the presence of specific DNA are usually considered as conclusive evidence (Dubey and Schares, 2006).

In the present study, the seroprevalence against $N$. caninum was investigated in cattle farms in Algeria and a case control study was performed to determine the role of $N$. caninum in cattle abortion in these farms. Finally, a few aborted fetuses were examined for the presence of $N$. caninum.

\section{MATERIALS AND METHODS}

\section{Animals}

The owners of 87 farms were willing to participate. From these farms, 799 cattle were enrolled in this study. The farms were located in the northern (Algiers County and Blida) or the eastern regions of Algeria (Bejaia and Setif). These areas represented approximately $25,000 \mathrm{~km}^{2}$. The sampling took place from November 2006 to January 2009. The farms were classified into 3 groups according to the breed of cattle: group 1 (European imported cattle such as Holstein, Primholstein, Frisean, Montbeliarde, or Fleckvie, 30 farms; $\mathrm{n}=324$ ); group 2 (local breeds such as the Brown of Atlas, 14 farms; $\mathrm{n}=105$ ); and group 3 (crosses between local and European breeds, 43 farms; $n=370$ ).

\section{Case control study}

A farm was considered as a case when at least 1 abortion event was recorded during the previous $5 \mathrm{yr}$, whereas a farm was considered as a control if no abortion event occurred during the same period of time. Among the 87 farms, 30 were considered as case and 57 as controls. The farm size was slightly larger $(P=0.03)$ for case $(24 \pm 28.9)$ than for controls $(14 \pm 12.8)$.

\section{Serology}

Ten milliliters of whole blood was collected from the tail vein of each animal. The tubes were centrifuged for $10 \mathrm{~min}$ at $2,700 \mathrm{~g}$ and the sera stored at $-20 \mathrm{C}$ until further use. An IFAT was performed as previously described (Ghalmi et al., 2009b). To determine the cutoff for the test, a validation step was performed on 100 sera by comparing IFAT results to a 
previously validated ELISA (Herdcheck Idexx Laboratories, Westbrook, Maine). This test is largely used in cattle for the determination of seroprevalence against $N$. caninum (Wu et al., 2002). The sera were diluted serially from $1 / 100$ to $1 / 1,600$ and the specificity, the sensitivity, and the coefficient of Kappa were calculated with the ELISA used as a reference. The results indicated that the best agreement was found when the 1/200 dilution was used (sensitivity $=90 \%$, specificity $=100 \%$, and Kappa $=$ 0.82 ). Therefore, a positive sample for IFAT was only considered at a dilution $>1 / 200$. The positive samples in IFAT were confirmed by immunoblotting as previously described (Ghalmi et al., 2009b). A farm was considered as positive for $N$. caninum if at least 1 animal was seropositive. The serological status of dogs present in case $(n=26)$ and in control farms $(\mathrm{n}=41)$ was investigated by IFAT as previously described (Ghalmi et al., 2009b). Cattle sera from case farms were tested against Bovine Herpes Virus 1, Bovine Herpes virus 4, and Bovine Viral Diarrhea Virus by ELISA (Bio-X, Jemelle, Belgium). The risk for each pathogen and the probability to cause abortion values were calculated in accordance with the literature (Hall et al., 2005)

\section{Aborted fetuses}

The brains of aborted fetuses were collected. A small piece ( $10 \mathrm{~g}$ ) was kept for PCR and several small fragments were stored in $10 \%$ formaldehyde for histological examination (hematoxylin and eosin-stained preparations) For PCR, DNA was extracted with the use of a Chemagenic DNA tissue kit (Chemagen, Achen, Germany). Two PCR systems were used, i.e., classic PCR targeting the ITS1 DNA region (Payne and Ellis, 1996) and a previously described real-time PCR targeting the NC5 DNA region (Ghalmi et al., 2008). For ITS1 PCR (Payne and Ellis, 1996), an internal PCR control has been developed by amplifying invA gene of Salmonella typhimurium with the use of CI-ITS1F (5'-gctgataatgaaagtgtgccggaagtattgtt-3') and CI-TS1R (5'-aaataacggtgtgggaaaa cetcttcatgcgttacccag-3') primers. The resulting amplicon (240 base pairs [bp]) has been reamplified by $N$. caninum-specific primers NS1 (5'-gctgataatgaaagtgtg- $\left.3^{\prime}\right)$ and SR1 $\left(5^{\prime}\right.$-aaataacggtgtgggaaaa- $\left.3^{\prime}\right)$. The resulting amplicon was diluted and the lowest amplifiable amount was determined and used as internal PCR control. For ITS1 PCR, the PCR mixture included $50 \mathrm{ng}$ of target DNA, $1 \mathrm{U}$ of Taq polymerase (New England Biolabs, Ipswich, Massachusetts), $2 \mu \mathrm{l}$ of $10 \times$ thermopolbuffer $\left(200 \mathrm{mM}\right.$ Tris- $\mathrm{HCl}, 100 \mathrm{mM}\left[\mathrm{NH}_{4}\right]_{2} \mathrm{SO}_{4}, 100 \mathrm{mM}$ $\mathrm{KCl}, 20 \mathrm{mM} \mathrm{MgSO}, 1 \%$ Triton X-100), pH 8.8 at $25 \mathrm{C}, 400 \mathrm{nM}$ of each primer, $1 \mu \mathrm{l}$ of internal PCR control, $200 \mu \mathrm{M} \mathrm{dNTP}$, NAT water up to $20 \mu \mathrm{l}$. The amplification cycles were as follows: 1 cycle for $5 \mathrm{~min}$ at $95 \mathrm{C}, 40$ cycles at $95 \mathrm{C}$ for $30 \mathrm{sec}, 50 \mathrm{C}$ for $30 \mathrm{sec}, 72 \mathrm{C}$ for $30 \mathrm{sec}, 1 \mathrm{cycle}$ at $72 \mathrm{C}$ for $5 \mathrm{~min}$. The PCR products were analyzed by $2 \%$ gel agarose electrophoresis. The target DNA was $137 \mathrm{bp}$ and the IPC was $240 \mathrm{bp}$.

\section{RESULTS}

\section{Statistics}

Specificity, sensitivity, Kappa, odds ratios, and confidence intervals were calculated with the use of Winepiscope 2.0 and Stat A 9.1 software.

\section{Seroprevalence}

Overall, 52.9\% of herds (46/87) had at least 1 seropositive animal. Seroprevalences within herds varied from 0 to $100 \%$. Of 799 serum samples, $157(19.6 \%)$ were positive (confidence interval 95\%: 16.8-22.5). When the different cattle groups are considered, the seroprevalences were $16.0 \%$ (11.9-20.1), 34.3\% (25.0-43.5), and $18.6 \%$ (14.6-22.6) in groups 1, 2, and 3, respectively. The seroprevalence in cattle of the local breeds (group 2) was significantly $(P<0.01)$ higher than in the 2 other populations. All positive samples were confirmed as positive by immunoblot.

\section{Case control study}

Among the 87 studied farms, 30 (34.5\%) were considered as case and $57(65.5 \%)$ as control with respect to the presence or absence of
TABLE I. Association between seroprevalence and abortion.

\begin{tabular}{lcc}
\hline & Case & Control \\
\hline Seropositive & 26 & 30 \\
Seronegative & 4 & 37 \\
Total & 30 & 57 \\
Prevalence & $86.7 \%$ & $35.1 \%$ \\
Odds ratio (confidence interval 95\%) & \multicolumn{2}{c}{$12.0(3.7-39.3)$} \\
\hline
\end{tabular}

abortion events during the previous 5 yr. Among the 799 sampled cattle, $369(46.2 \%)$ belonged to case farms and $430(53.8 \%)$ to control farms. Among the 57 control farms, 20 (35.1\%) were seropositive for $N$. caninum and $37(64.9 \%)$ were negative, whereas among the 30 case farms, $26(86.7 \%)$ were seropositive and 4 $(13.3 \%)$ seronegative. The seroprevalence within herds varied from 0 to $100 \%$ in case farms, and from 0 to $57.1 \%$ in control farms. The association between seroprevalence and abortion was calculated with the use of odds and risk ratios (Table I). The risk and odds ratios were significantly greater than 1 , indicating an association between seroprevalence to $N$. caninum and the presence of abortion events on the farms. Furthermore, when individual seroprevalence was considered with respect to the origin of a given animal (case versus control), the calculated OR and RR were still significant (Table II). Finally, when the data were analyzed according to the breed, a significant association $(P<0.01)$ was observed in groups 1 and 3 , but not in group $2(P>0.05)$ (Table III).

\section{Dog involvement}

Previously (Ghalmi, Dramchini et al., 2009), we have shown that there was an association between the presence of dogs and abortion in cattle farms in Algeria. Here, we investigated this association more thoroughly. When the serological status of dogs was compared with the presence of abortions in farms (Table IV), a strong association was observed $(P<0.01)$ between the serological status of dogs and the probability of abortion.

\section{Other abortions causes}

The sera of cattle from case farms $(n=320)$ were tested for the presence of antibodies against BHV1, BHV4, and BVD viruses, which are the major viral causes of abortion in cattle. Twenty-one $(6.5 \%), 35(10.9 \%)$, and $71(22.2 \%)$ sera were positive for BHV1, BVD, and BHV4, respectively. The overall seroprevalence of $N$. caninum in the same serum samples was $27.2 \%$. Among the tested sera, 54 belonged were from aborting cows. Among these 54 sera, $26,8,13$, and 1 were positive for $N$. caninum, BVDV, BHV4, and $\mathrm{BHV} 1$, respectively. Therefore, it was possible to calculate risk for each pathogen, i.e., 17.9, 6.7, 1.8, and 0 for $N$. caninum, BVDV,

TABLE II. Case control study at the cattle level.

\begin{tabular}{lcc}
\hline & $\begin{array}{c}\text { Cattle from } \\
\text { case farms }\end{array}$ & $\begin{array}{c}\text { Cattle from } \\
\text { control farms }\end{array}$ \\
\hline Seropositive & 104 & 53 \\
Seronegative & 265 & 377 \\
Total & 369 & 430 \\
Prevalence & $28.2 \%$ & $12.3 \%$ \\
Odds ratio (confidence interval 95\%) & \multicolumn{2}{c}{$2.8(1.9-4.0)$} \\
\hline
\end{tabular}


TABLE III. Case control study at the cattle population level.

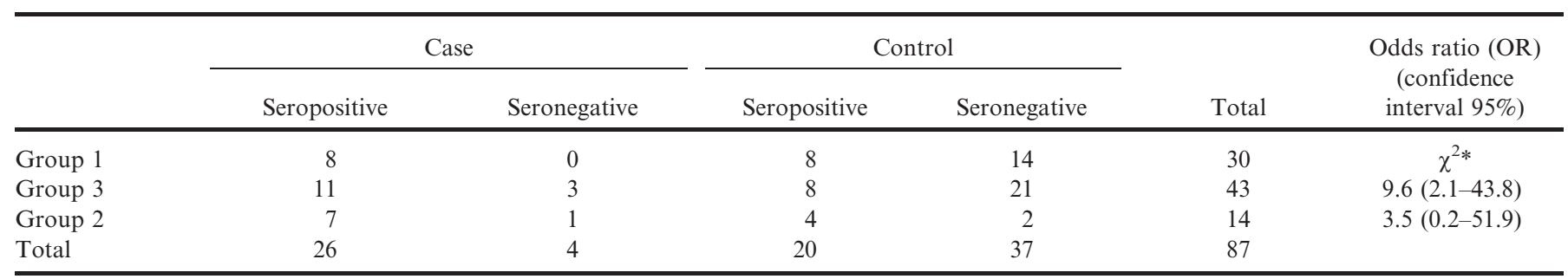

$* \mathrm{OR}=\infty$, the $\chi^{2}$ has been calculated and was significant $(P<0.01)$.

BHV4, and BHV1, respectively. The probability of causing abortion was also calculated for each relevant pathogen and was found to be $59.8 \%, 29.6 \%$, and $9.9 \%$ for $N$. caninum, BVDV, and BHV4, respectively. An increased risk of abortion (44.4\%) with concurrent infections ( $N$. caninum, BVDV, and BHV4) was observed.

\section{Aborted fetuses}

To confirm a direct link between $N$. caninum infection and abortion, 5 fetuses were analyzed. The serological status of the mothers was examined by IFAT. Four cows were positive and 1 was negative. The brains of fetuses were analyzed both by histology and PCR. For PCR, we used NC-5 real-time PCR and ITS1 classical PCR. Histological examination revealed the presence of compatible lesions in 1 fetus. This sample was also positive in PCR. Two additional samples were positive by PCR (NC-5 and ITS1), whereas the latter 2 were negative with both techniques.

\section{DISCUSSION}

The seroprevalence of $N$. caninum in bovine populations can vary according to country, region, methodology, and cutoff value (Dubey et al., 2007; Ghalmi et al., 2007). Our observation that $52.9 \%$ of the herds studied had at least 1 animal seropositive to $N$. caninum suggests that neosporosis is widespread among dairy herds in at least some parts of Algeria. In the present study, the sera of 799 Algerian cattle were examined and a global seroprevalence of $19.6 \%$ was recorded (16.8-22.5). This seroprevalence is comparable with those found in another studies using the same technique (IFAT) and the same cut off $(1 / 200)$, as that performed in Argentina (Moore et al., 2002, 2003), Brazil (Corbellini et al., 2006; Minervino et al., 2008), Japan (Koiwai et al., 2005), Korea (Hur et al., 1998), Australia (Atkinson et al., 2000), and the United States (Dyer et al., 2000).

Several studies indicated that $N$. caninum seropositive cows have a higher risk for abortion. Only a few real case control studies have been performed to evaluate the association between the presence of specific antibodies and the occurrence of abortion

TABLE IV. Association between dog seroprevalence and abortion in cattle farms.

\begin{tabular}{lcl}
\hline \multicolumn{1}{c}{ Dog } & Case & Control \\
\hline Seropositive & 25 & 14 \\
Seronegative & 1 & 27 \\
Total & 26 & 41 \\
Exposure rate & $96.15 \%$ & $34.41 \%$ \\
Odds ratio & \multicolumn{2}{c}{$48.21(5.9-393.9)$} \\
\hline
\end{tabular}

in cattle farms (De Meerschman et al., 2000; Vaclavek et al., 2003). In these studies, the OR ranged from 3.1 (De Meerschman et al., 2000) to 22.1 (Sager et al., 2001) and the results were significantly different from 1 . The present data are in agreement with the previous studies with an OR of 12.0 at the farm level and 2.8 at the individual level. Thurmond and Hietala (1995) considered that an OR of 2 indicated a state of endemic abortion, whereas a higher value was indicative of an epidemic situation.

Because dogs are the definitive host, the presence of dogs on a cattle farm is a major risk factor for the propagation of the parasite and for cattle abortion. The association between cattle abortion and the presence of dogs was previously investigated (Ghalmi, Dramchini et al., 2009). Here, we extended the analysis by determining the presence of antibodies against $N$. caninum in farm dogs and cattle abortion. There was a very clear association $(\mathrm{OR}=48.2)$ between the presence of seropositive dogs in farms and the occurrence of abortion. A cross infection between dogs and cattle is possible, because dogs infect cattle via contaminated food or water and cattle infect dogs via contaminated aborted fetuses. A similar observation was reported from Netherlands (Wouda et al., 1999) and Brazil (Guimaraes et al., 2004), showing a correlation between seropositivity to $N$. caninum in farm dogs and a high seroprevalence of neosporosis in cattle.

Additional tests were carried out on seropositive animals from case farms. These indicated that viral pathogens like BHV1, BHV4, and BVDV also may be responsible for abortions. However, $N$. caninum clearly appears to be the most important agent for abortion in cattle.

The present study also demonstrated an increased risk of abortion when infection is concurrent among N. caninum, BHV4, and BVD (44.4\% versus $28.6 \%$ ). However, in another study, Davison et al. (1999) was unable to demonstrate the existence of an association between $N$. caninum, BVD, IBRV, and Leptospira hardjo-bovis.

\section{ACKNOWLEDGMENTS}

This work was supported by a grant of the Algerian ministry of higher education and the Belgian Technical Cooperation.

\section{LITERATURE CITED}

Atrinson, R. A., R. W. Cook, L. A. Reddacliff, J. Rothwell, K. W. Broady, P. Harper, and J. T. Ellis. 2000. Seroprevalence of Neospora caninum infection following an abortion outbreak in a dairy cattle herd. Australian Veterinary Journal 78: 262-266.

Baszler, T. V., L. J. Gay, M. T. Long, and B. A. Mathison. 1999. Detection by PCR of Neospora caninum in fetal tissues from spontaneous bovine abortions. Journal Clinical of Microbiology 37: $4059-4064$

Corbellini, L. G., D. R. Smith, C. A. Pescador, M. Schmitz, A. Correa, D. J. Steffen, and D. Driemeier. 2006. Herd-level risk factors for 
Neospora caninum seroprevalence in dairy farms in southern Brazil. Preventive Veterinary Medicine 74: 130-141.

Davison, H. C., A. Otter, and A. J. Trees. 1999. Significance of Neospora caninum in British dairy cattle determined by estimation of seroprevalence in normally calving cattle and aborting cattle. International Journal for Parasitology 29: 1189-1194.

De Meerschman, F., C. Focant, R. Boreux, T. Leclipteux, and B. Losson. 2000. Cattle neosporosis in Belgium: A case-control study in dairy and beef cattle. International Journal for Parasitology 30: 887-890.

Dubey, J. P., D. Buxton, And W. Wouda. 2006. Pathogenesis of bovine neosporosis. Journal of Comparative Pathology 134: 267-289.

- A. L. Hattel, D. S. Lindsay, and M. J. Topper. 1988. Neonatal Neospora caninum infection in dogs: Isolation of the causative agent and experimental transmission. Journal of the American Veterinary Medical Association 193: 1259-1263.

—, AND D. S. LindSAY. 1993. Neosporosis. Parasitology Today 9: $452-458$

—, AND G. Schares. 2006. Diagnosis of bovine neosporosis. Veterinary Parasitology 140: 1-34.

- - and L. M. Ortega-Mora. 2007. Epidemiology and control of neosporosis and Neospora caninum. Clinical Microbiology Reviews 20: 323-367.

Dyer, R. M., M. C. Jenkins, O. C. Kwok, L. W. Douglas, and J. P. DubeY. 2000. Serologic survey of Neospora caninum infection in a closed dairy cattle herd in Maryland: Risk of serologic reactivity by production groups. Veterinary Parasitology 90: 171-181.

Ghalmi, F., B. China, And B. Losson. 2007. Diagnostic et surveillance épidémiologique de Neospora caninum. Annales de Médecine Véterinaire 151: 123-149.

- - R. Kaidi, G. Daube, and B. Losson. 2008. Detection of Neospora caninum in dog organs using real time PCR systems. Veterinary Parasitology 155: 161-167.

, - — AND B. Losson. 2009a. Evaluation of a SRS2 sandwich commercial enzyme-linked immunosorbent assay for the detection of anti-Neospora caninum antibodies in bovine and canine sera. Journal Veterinary Diagnosis and Investigation 21: 108-111.

$\longrightarrow$ - $\longrightarrow$ AND $\longrightarrow$ 2009b. First epidemiological study on exposure to Neospora caninum in different canine populations in the Algiers District (Algeria). Parasitology International 58: 444-450.

, N. Dramchini, and B. China. 2009. Risk factors for abortion in cattle herds in Algeria. Veterinary Record 165: 475-476.

Guimaraes, J. S., Jr., S. L. Souza, D. P. Bergamaschi, and S. M. GenNARI. 2004. Prevalence of Neospora caninum antibodies and factors associated with their presence in dairy cattle of the north of Parana state, Brazil. Veterinary Parasitology 124: 1-8.

Hall, C. A., M. P. Reichel, AND J. T. Ellis. 2005. Neospora abortions in dairy cattle: Diagnosis, mode of transmission and control. Veterinary Parasitology 128: 231-241.

Hur, K., J. H. Kim, W. S. Hwang, E. K. Hwang, Y. H. Jean, B. C. Lee, J. S. Bae, Y. B. Kang, I. Yamane, and D. Y. Kim. 1998 Seroepidemiological study of Neospora caninum in Korean dairy cattle by indirect immunofluorescent antibody assay. Korean Journal of Parasitology 38: 859-866.

Koiwai, M., T. Hamaoka, M. Haritani, S. Shimizu, T. Tsutsui, M. Eto, AND I. YAmANE. 2005. Seroprevalence of Neospora caninum in dairy and beef cattle with reproductive disorders in Japan. Veterinary Parasitology 130: 15-18.

Lindsay, D. S., B. L. Blagburn, and J. P. Dubey. 1992. Factors affecting the survival of Neospora caninum bradyzoites in murine tissues. Journal of Parasitology 78: 70-72.
Parasitology 14: 1-11.

McAllister, M. M. 1999. Uncovering the biology and epidemiology of Neospora caninum. Parasitology Today 15: 216-217.

Minervino, A. H., A. M. Ragozo, R. M. Monteiro, E. L. Ortolani, and S. M. Gennari. 2008. Prevalence of Neospora caninum antibodies in cattle from Santarém, Pará, Brazil. Research in Veterinary Science 84: 254-256.

Moore, D. P., C. M. Campero, A. C. Odeon, R. Chayer, and M. A. Bianco. 2003. Reproductive losses due to Neospora caninum in a beef herd in Argentina. Journal of Veterinary Medicine B, Infectious Diseases and Veterinary Public Health 50: 304-308.

- M. A. Posso, D. Cano, M. R. Leunda, W. Basso, M. C. Venturini, And E. Spath. 2002. Seroepidemiology of beef and dairy herds and fetal study of Neospora caninum in Argentina. Veterinary Parasitology 107: 303-316.

Mưller, N., N. Vonlaufen, C. Gianinazzi, S. L. Leib, and A. Hemphill. 2002. Application of real-time fluorescent PCR for quantitative assessment of Neospora caninum infections in organotypic slice cultures of rat central nervous system tissue. Journal Clinical of Microbiology 40: 252-255.

,V. Zimmermann, B. Hentrich, and B. Gottstein. 1996. Diagnosis of Neospora caninum and Toxoplasma gondii infection by PCR and DNA hybridization immunoassay. Journal Clinical of Microbiology 34: $2850-2852$.

Paula, V. S., A. A. Rodrigues, L. J. Richtzenhain, A. Cortez, R. M. Soares, and S. M. Gennari. 2004. Evaluation of a PCR based on primers to Nc5 gene for the detection of Neospora caninum in brain tissues of bovine aborted fetuses. Veterinary Research Communications 28: 581-685.

Payne, S., AND J. Ellis. 1996. Detection of Neospora caninum DNA by the polymerase chain reaction. International Journal for Parasitology 26: $347-351$.

Sager, H., I. Fischer, K. Furrer, M. Strasser, A. Waldvogel, P. Boerlin, L. Audige, and B. Gottstein. 2001. A Swiss case-control study to assess Neospora caninum-associated bovine abortions by PCR, histopathology and serology. Veterinary Parasitology 102: 115.

Thurmond, M., and S. K. Hietala. 1995. Strategies to control Neospora infection in cattle. Bovine Practice 29: 60-63.

Vaclavek, P., B. Koudela, D. Modry, and K. Sedlak. 2003. Seroprevalence of Neospora caninum in aborting dairy cattle in the Czech Republic. Veterinary Parasitology 115: 239-245.

Wouda, W., J. Brinkhof, C. van Mannen, A. L. De Gee, and A. R. MoEn. 1998. Serodiagnosis of neosporosis in individual cows and dairy herds: A comparative study of three enzyme-linked immunosorbent assays. Clinical and Diagnostic Laboratory Immunology 5: 711-716.

— T. Dijkstra, A. M. Kramer, C. Van MaAnen, and J. M. BRINKHOF. 1999. Seroepidemiological evidence for a relationship between Neospora caninum infections in dogs and cattle. International Journal for Parasitology 29: 1677-1682.

Wu, J. T., S. Dreger, E. Y. Chow, And E. E. Bowlby. 2002. Validation of 2 commercial Neospora caninum antibody enzyme linked immunosorbent assays. Canadian Journal of Veterinary Research 66: 264 271.

Yamage, M., O. Flechtner, and B. GotTstein. 1996. Neospora caninum: Specific oligonucleotide primers for the detection of brain "cyst" DNA of experimentally infected nude mice by the polymerase chain reaction (PCR). Journal of Parasitology 82: 272-279. 